\title{
The effects of environmental risk on consumption dynamics: an empirical analysis on the Mediterranean countries
}

\author{
DONATELLA BAIARDI
}

Department of Economics, Management and Statistics, University of Milano-Bicocca, Piazza dell'Ateneo Nuovo, 1-20126, Milan, Italy. Email: donatella.baiardi@unimib.it

\section{MATTEO MANERA}

Department of Economics, Management and Statistics, University of Milano-Bicocca, Milan, and Fondazione Eni Enrico Mattei, Milan, Italy. Email:matteo.manera@unimib.it

\author{
MARIO MENEGATTI \\ Department of Economics, University of Parma, Parma, Italy. \\ Email: mario.menegatti@unipr.it
}

Submitted 5 November 2014; revised 29 July 2015; accepted 9 November 2015; first published online 7 January 2016

\begin{abstract}
This paper estimates a theory-based regression model which studies the macro-economic impact of environmental and consumption risks on consumption growth in the Mediterranean region. The analysis is carried out using time series aggregate data for 13 Mediterranean countries over the period 1965-2008. The results indicate that both risks and their interaction significantly influence consumption dynamics. The estimates of the indices of relative risk aversion and relative prudence, as well as the relative preference for the quality of environment, suggest marked cross-country heterogeneity.
\end{abstract}

The authors would like to thank seminar participants at the Department of Economics, University of Parma, Italy; the Department of Economics, Management and Statistics, University of Milano-Bicocca, Italy; the Department of Economics, Management and Quantitative Methods, University of Milano, Italy; and the Fondazione Eni Enrico Mattei, Milan, Italy for useful comments on previous versions of this paper. Matteo Manera acknowledges financial support from the MIUR research program entitled 'Climate Change in the Mediterranean Area: Scenarios, Economic Impacts, Mitigation Policies and Technological Innovation' (PRIN 2010-11, Prot. No. 2010S2LHSE-001). 


\section{Introduction}

As documented by a wide body of literature, uncertainties about environmental conditions and environmental risk are very important factors affecting the dynamics of several key macroeconomic variables.

From a growth theory perspective, Heal (1984) and Keeler et al. (2004) analyze the effects of uncertainty on future productivity changes due to pollution, while Soretz (2007) studies the impacts on output of uncertainty on the quality of environment. Ulph and Ulph (1997) and Pindyck (2000, 2002) examine the optimal timing for environmental policies in a real option framework. Fan et al. $(2010,2012)$ find that uncertainty and risk aversion have significant policy implications in terms of investment incentives. Baiardi and Menegatti (2011) demonstrate that different kinds of environmental uncertainty influence the size of public intervention.

A recent stream of theoretical research investigates consumption and saving decisions under the contemporaneous presence of a risk on wealth affecting the level of consumption (henceforth, consumption risk) and a background risk, which typically involves environmental quality or environmental conditions (henceforth, environmental risk). In particular, Courbage and Rey (2007); Menegatti (2009a, b) and Denuit et al. (2011) examine consumption dynamics under different assumptions on the size and distribution of environmental and consumption risks.

In the empirical literature on consumption dynamics, the traditional approach considers consumption risk as isolated (see Dynan, 1993; Hahm and Steigerwald, 1999; Guariglia and Kim, 2003; and Menegatti, 2007, 2010), while Baiardi et al. (2013) provide the first empirical analysis which combines consumption risk with environmental risk. Their results support the conclusion that the interaction between these two sources of risk significantly influences consumption.

In this paper we use a theory-based model to investigate the macroeconomic effects on consumption dynamics and the saving of environmental and consumption risks, jointly considered, in the Mediterranean (MED) region.

With respect to the previous literature, the novelties of our paper are threefold. First, the subject of our empirical analysis is represented by countries which share a very peculiar and crucial geographical location. In this respect, our paper is new, since it deals with 13 MED countries (Albania, Algeria, Croatia, Cyprus, Egypt, Greece, Israel, Lebanon, Malta, Morocco, Slovenia, Tunisia and Turkey) during the period 1965-2008. We deliberately exclude France, Italy and Spain from the group of analyzed countries, since they are likely to be characterized by a degree of environmental awareness which is significantly different from that of the other MED countries. Moreover, we believe that focusing on the selected countries, especially the less advanced ones, is more interesting and informative, especially in light of the process of economic and cultural modernization which many of those countries are currently experiencing. Finally, our choice contributes to the innovative nature of this study, since, to the best of our knowledge, very few papers in the empirical literature on environmental economics specifically deal with the MED countries, and none 
of them tackles the issue of investigating the macroeconomic impacts of environmental risk. ${ }^{1}$

Besides their geographical proximity, the MED countries are characterized by a long history of cooperation on environmental conservation initiatives (Kagiannas et al., 2003; Gürlük, 2009). Many international projects involving the MED countries have been approved to foster environmental protection, reduce air and water pollution and facilitate the diffusion of renewable resources. Among them, it is worth noting the Initiative Horizon 2020 (EU, 2006), a comprehensive environmental strategy aimed at reducing industrial and urban pollution, implementing environmental laws and developing deeper knowledge about the environment. Other initiatives are the Mediterranean Strategy for Sustainable Development (MSSD, 2005) and the International Augmented Med (IAM, 2012), whose purpose is to reduce the gap between developed and developing countries in the region. Some projects, such as the European Neighborhood Policy (ENP, 2004) and the Mediterranean Action Plan (UNEP/MAP, 2004), are instead related to preservation of the Mediterranean Sea. More importantly, new and increasing attention regarding the role of environmental risks is acknowledged. This recent attitude is demonstrated by different projects, such as European Mediterranean Sea Acidification (MedSeA, 2011) in a changing climate, which aims to assess the effects of different kinds of uncertainty related to MED acidification at organismal, ecosystem and economic levels.

Secondly, our paper provides readers with fresh empirical evidence on the indices of relative risk aversion and relative prudence, and on the relative preference for the quality of environment in each MED country. Such measures of general attitude toward the environment are particularly relevant for the MED economies, since they are strongly heterogeneous in terms of economic development and social and cultural features, as well as environmental conditions. Moreover, a significant number of the major MED countries are currently experiencing profound economic and social instabilities, which will probably renew interest in how different sources of uncertainty impact on economic choices. Therefore, an assessment of the country-specific attitude toward environmental risk, coupled with a quantification of a country's relative preference for the quality of environment, conveys crucial information which should be at the basis of any attempt to implement country-specific policy and environmental reforms.

Thirdly, our approach is radically different from virtually all the studies published so far on environmental and energy economics issues related to the MED region. Actually, our paper is innovative compared to more traditional studies which examine the potential of international projects in the MED area (see, among others, Kagiannas et al., 2003; Karakosta et al., 2010; Reiche, 2010; Karakosta and Psarras, 2013), and with respect to the literature focusing on more specific topics, such as the implementation of renewable resources (Jacobson and Delucchi, 2010; Jablonski et al., 2012;

${ }^{1}$ See Baiardi et al. (2013) for a similar analysis carried out on a number of OECD countries, including France, Italy and Spain. 
Komendantova et al., 2012; Cambini and Franzi, 2013) or the impact of energy consumption on the environment (Arouri et al., 2012).

The paper is organized as follows. Section 2 illustrates the theoretical model and its econometric specification. The data set is described in section 3. Section 4 discusses the main empirical results. The indices of relative risk aversion and of relative prudence, together with the relative preference for the quality of environment, are presented for each country in section 5. Section 6 concludes.

\section{The theoretical model and the estimated equations}

We describe consumers' preferences at time $t$ in a multiperiod framework, using a two-argument utility function $U\left(C_{t}, E_{t}\right)$, where $C_{t}$ is consumption and $E_{t}$ is the level of environment quality. We assume that the level of $E_{t}$ is given for the agent (see Smulders and Gradus, 1996; Ayong Le Kama and Schubert, 2004). We also assume that $U\left(C_{t}, E_{t}\right)$ is increasing and concave with respect to each of its arguments; that is: $U_{C}\left(C_{t}, E_{t}\right)>0, U_{E}\left(C_{t}, E_{t}\right)>0, U_{C C}\left(C_{t}, E_{t}\right)<0$ and $U_{E E}\left(C_{t}, E_{t}\right)<0$, where $U_{C}\left(C_{t}, E_{t}\right) \equiv \partial U / \partial C, U_{E}\left(C_{t}, E_{t}\right) \equiv \partial U / \partial E, U_{C C}\left(C_{t}, E_{t}\right) \equiv \partial^{2} U / \partial C^{2}$ and $U_{E E}\left(C_{t}, E_{t}\right) \equiv \partial^{2} U / \partial E^{2}$. Similarly, we define the third derivatives of the utility function as: $U_{C C C}\left(C_{t}, E_{t}\right) \equiv \partial^{3} U / \partial C^{3}, U_{C C E}\left(C_{t}, E_{t}\right) \equiv$ $\partial^{3} U / \partial C^{2} \partial E$ and $U_{C E E}\left(C_{t}, E_{t}\right) \equiv \partial^{3} U / \partial C \partial E^{2}$. Conditions $U_{C C}\left(C_{t}, E_{t}\right)<0$ and $U_{E E}\left(C_{t}, E_{t}\right)<0$ are particularly important, since they indicate aversion toward risk on consumption and aversion toward risk on the quality of the environment, respectively.

We extend the univariate framework of Carroll $(1992,1997)$ by means of the bivariate intertemporal consumption model:

$$
\begin{gathered}
\max _{C_{t}} \mathbb{E} \sum_{t=0}^{T} \beta^{t} U\left(C_{t}, E_{t}\right) \\
W_{t+1}=(1+r)\left(W_{t}+Y_{t}-C_{t}\right)
\end{gathered}
$$

where $Y$ is income, $W$ is net wealth, $r$ is the constant interest rate, $R=1+r$ is the interest factor, $\delta$ is the subjective intertemporal discount rate, and $\beta=1 /(1+\delta)$ is the subjective intertemporal discount factor.

According to a wide strand of literature, we analyze consumption dynamics assuming that income and interest rate are exogenous. ${ }^{2}$ Consequently, we do not model either production or financial markets. It is crucial to emphasize that, from an empirical perspective, this partial equilibrium approach provides a clearer and more direct interpretation of the

2 Starting from the seminal paper by Hall (1978) and the fundamental contributions by Carroll $(1992,1997)$ and Dynan $(1993)$, the effect of uncertainty is typically studied by estimating a Euler equation, such as equation (5) below, which assumes the exogeneity of income and interest rate (e.g., Hahm, 1999; Hahm and Steigerwald, 1999; Lyhagen, 2001; Giles and Yoo, 2007; Menegatti, 2007, 2010; Baiardi et al., 2013; Bande and Riveiro, 2013). 
empirical results. Actually, we are able to derive comparable estimates for parameters measuring risk aversion and preferences for environmental quality for each MED country.

Problem (1) is solved by maximizing the Lagrangian:

$$
L=\mathbb{E} \sum_{t=0}^{T} \beta^{t}\left[U\left(C_{t}, E_{t}\right)-\lambda_{t}\left(W_{t+1}-R\left(W_{t}+Y_{t}-C_{t}\right)\right)\right]
$$

The first-order conditions are:

$$
\begin{aligned}
\frac{\partial L}{\partial C_{t}} & =\beta^{t}\left[U_{C}\left(C_{t}, E_{t}\right)-R \lambda_{t}\right]=0, \\
\frac{\partial L}{\partial W_{t+1}} & =-\beta^{t} \lambda_{t}+\beta^{t+1} R \mathbb{E}\left[\lambda_{t+1}\right]=0, \\
\frac{\partial L}{\partial \lambda_{t}} & =W_{t+1}-R\left(W_{t}+Y_{t}-C_{t}\right)=0 .
\end{aligned}
$$

Combining first-order conditions (2) and (3), we obtain the Euler's equation:

$$
\beta R \mathbb{E}\left[U_{C}\left(C_{t+1}, E_{t+1}\right)\right]=U_{C}\left(C_{t}, E_{t}\right)
$$

Following Dynan (1993), we substitute a second-order Taylor approximation of $U_{c}\left(C_{t}, E_{t}\right)$ into the left-hand side of condition (5), obtaining the condition:

$$
\begin{aligned}
\mathbb{E}\left[\frac{\left(C_{t+1}-C_{t}\right)}{C_{t}}\right]= & \frac{1-\beta R}{\beta R} \frac{U_{C}}{C_{t} U_{C C}}-\mathbb{E}\left[\left(E_{t+1}-E_{t}\right)\right] \frac{U_{C E}}{C_{t} U_{C C}} \\
& -\frac{1}{2} \mathbb{E}\left[\left(C_{t+1}-C_{t}\right)^{2}\right] \frac{U_{C C C}}{C_{t} U_{C C}}-\frac{1}{2} \mathbb{E}\left[\left(E_{t+1}-E_{t}\right)^{2}\right] \frac{U_{C E E}}{C_{t} U_{C C}} \\
& -\mathbb{E}\left[\left(C_{t+1}-C_{t}\right)\left(E_{t+1}-E_{t}\right)\right] \frac{U_{C C E}}{C_{t} U_{C C}}
\end{aligned}
$$

Along the lines suggested by Smulders and Gradus (1996), Ayong Le Kama and Schubert (2004) and Baiardi et al. (2013), we consider the twoargument constant relative risk aversion (CRRA) utility function:

$$
U\left(C_{t}, E_{t}\right)=\frac{C_{t}^{1-\gamma} E_{t}^{\phi(1-\gamma)}-1}{1-\gamma}
$$

where $\gamma>0$ and $\phi>0$ are the parameters of interest. Parameter $\gamma$ represents the index of relative risk aversion $\left(-\frac{U_{C C} C_{t}}{U_{C}}\right)$, while the index of relative prudence $\left(-\frac{U_{C C C} C_{t}}{U_{C C}}\right)$ is equal to $1+\gamma$. Note that $\gamma>0$ ensures risk aversion toward uncertainty on consumption (i.e., $U_{C C}<0$ ). On the other hand, parameter $\phi=\frac{U_{E} E_{t}}{U_{C} C_{t}}$ ' $[\ldots]$ represents relative preference for environmental quality [...]' (see Ayong Le Kama and Schubert, 2004: 34). 
Using specification (7), risk aversion toward the quality of environment requires:

$$
U_{E E}=\phi[\phi(1-\gamma)-1] C_{t}^{1-\gamma} E_{t}^{\phi(1-\gamma)-2}<0 .
$$

This condition has some implications for the sign of the coefficients to be estimated, discussed below. Moreover, it implies an additional restriction between parameters $\gamma$ and $\phi$, given by

$$
\gamma>1-\frac{1}{\phi}
$$

Uncertainty is introduced into the model by assuming that both arguments of the utility function are affected by random shocks. ${ }^{3}$ According to the empirical literature which starts from Carroll (1992) and studies the effects of multiple sources of uncertainty on optimal consumption level, we do not explicitly model any of the risks involved in the analysis. ${ }^{4}$

The environmental quality level $E_{t}$ is difficult to measure directly. In this paper, we assume $E_{t}=P_{t}^{-1}$; that is, the level of environmental quality is a decreasing function of the level of pollution $P_{t}$. This assumption, together with equation (7), implies that our utility function becomes

$$
U\left(C_{t}, P_{t}\right)=\frac{C_{t}^{1-\gamma} P_{t}^{-\phi(1-\gamma)}-1}{1-\gamma} .
$$

Combining equation (6) with specification (10), we obtain:

$$
\begin{aligned}
\mathbb{E}\left[\frac{\left(C_{t+1}-C_{t}\right)}{C_{t}}\right]= & \frac{r-\delta}{(1+r) \gamma}-\frac{\phi(1-\gamma)}{\gamma} \mathbb{E}\left[\frac{\left(P_{t+1}-P_{t}\right)}{P_{t}}\right] \\
& +\frac{(1+\gamma)}{2} \mathbb{E}\left[\frac{\left(C_{t+1}-C_{t}\right)}{C_{t}}\right]^{2}+\frac{\phi(1-\gamma)[\phi(1-\gamma)+1]}{2 \gamma} \\
& \times \mathbb{E}\left[\frac{\left(P_{t+1}-P_{t}\right)}{P_{t}}\right]^{2} \\
& +\phi(1-\gamma) \mathbb{E}\left[\frac{\left(C_{t+1}-C_{t}\right)}{C_{t}} \frac{\left(P_{t+1}-P_{t}\right)}{P_{t}}\right]
\end{aligned}
$$

Consequently, given that $\Delta \log \left(C_{t+1}\right) \cong \frac{C_{t+1}-C_{t}}{C_{t}}$ and $\Delta \log \left(P_{t+1}\right) \cong$ $\frac{P_{t+1}-P_{t}}{P_{t}}$, equation (11) can be re-written as:

$$
\begin{aligned}
\Delta \log \left(C_{t+1}\right)= & \alpha_{0}+\alpha_{1} \Delta \log \left(P_{t+1}\right)+\alpha_{2} \operatorname{Var}_{t}\left[\Delta \log \left(C_{t+1}\right)\right] \\
& +\alpha_{3} \operatorname{Var}_{t}\left[\Delta \log \left(P_{t+1}\right)\right] \\
& +\alpha_{4} \operatorname{Cov}_{t}\left[\Delta \log \left(C_{t+1}\right), \Delta \log \left(P_{t+1}\right)\right]+u_{t+1}
\end{aligned}
$$

3 See Hahm and Steigerwald (1999) and Baiardi et al. (2013).

4 See Courbage and Rey (2007); Eeckhoudt et al. (2007); Menegatti (2009a, b); Denuit et al. (2011); Courbage (2014); Baiardi et al. (2015). 
where

$$
\begin{aligned}
& \alpha_{0}=\frac{r-\delta}{(1+r) \gamma}, \\
& \alpha_{1}=-\frac{\phi(1-\gamma)}{\gamma}, \\
& \alpha_{2}=\frac{(1+\gamma)}{2}, \\
& \alpha_{3}=\frac{\phi(1-\gamma)[\phi(1-\gamma)+1]}{2 \gamma}, \\
& \alpha_{4}=\phi(1-\gamma) .
\end{aligned}
$$

It is important to note that the term $\operatorname{Var}_{t}\left[\Delta \log \left(C_{t+1}\right)\right]$ in equation (12) describes consumption variability due to random shocks and measures consumption risk. Similarly, the term $\operatorname{Var}_{t}\left[\Delta \log \left(P_{t+1}\right)\right]$ indicates the variability in environmental conditions and proxies environmental risk. Finally, the covariance term $\operatorname{Cov}_{t}\left[\Delta \log \left(C_{t+1}\right), \Delta \log \left(P_{t+1}\right)\right]$ represents the interaction between the rate of growth of consumption and the rate of growth of pollution. According to equation (12), the rate of growth of consumption is directly influenced by the rate of growth of pollution, consumption risk and environmental risk, and indirectly affected by the interaction between the two risks through the covariance between the two growth rates. ${ }^{5}$

Furthermore, from conditions (14) and (15) we obtain:

$$
\gamma=2 \alpha_{2}-1
$$

and

$$
\phi=\frac{-\alpha_{1} \gamma}{(1-\gamma)}
$$

Moreover, combining equation (17) with equation (18), condition (14) can be rewritten as:

$$
\alpha_{1}=\frac{-\alpha_{4}}{2 \alpha_{2}-1}
$$

and, similarly, from equations (14), (16) and (17), we derive:

$$
\alpha_{3}=-\frac{1}{2} \alpha_{1}\left[\alpha_{4}+1\right]
$$

${ }^{5}$ As pointed out by a referee, the direct effect of the interaction between consumption risk and environmental risk on consumption dynamics, which should be given by the covariance between the variances of the two rates of growth (co-risk), is not present in equation (12). This is due to the second-order Taylor approximation underlying (12), which decomposes the variability of the utility into three terms, namely the variances of consumption and pollution growth rates and their covariance. Since the covariance between the two rates of growth can be seen as a component of the co-risk, we interpret the term $C O V_{t}$ in equation (12) as the indirect effect of co-risk on the consumption growth rate. 
Coefficient $\alpha_{1}$ introduces the direct effect of pollution on consumption growth rate, while coefficients $\alpha_{2}$ and $\alpha_{3}$ show the influence of consumption and environmental uncertainty on consumption dynamics. The covariance between the two growth rates, related to coefficient $\alpha_{4}$, describes the indirect effect of the interaction between the two risks. Note that the assumptions of our theoretical model have implications for the signs of these parameters. In particular, $\gamma>0$ ensures $\alpha_{2}>0$, while condition (8) implies that $\alpha_{4}<1$.

On the other hand, the theoretical model does not impose any a priori assumptions about the sign of coefficients $\alpha_{1}$ and $\alpha_{3}$. In order to have some theoretical indications about the sign of these coefficients, it is necessary to introduce an additional condition. In this respect, our model assumes aversion toward uncertainty on environmental quality $\left(U_{E E}<0\right)$, while equation (10) introduces an indirect measure of the environmental quality $E_{t}$ based on pollution $P_{t}$. Since the relationship between $E_{t}$ and $P_{t}$ is decreasing by assumption, but not linear, $U_{E E}<0$ does not guarantee that $U_{P P}<0$. Therefore, an additional condition is required, which indicates aversion toward uncertainty on the level of pollution:

$$
U_{P P}=\phi[\phi(1-\gamma)+1] C_{t}^{1-\gamma} P_{t}^{-\phi^{(1-\gamma)-2}}<0
$$

Notice that condition (22) implies $\alpha_{1}>0$ and $\alpha_{3}>0$. In other words, by introducing the assumption of aversion toward uncertainty on the level of pollution, we obtain a positive sign restriction on parameters $\alpha_{1}$ and $\alpha_{3}$.

Moreover, condition (22) implies a complementary restriction between parameters $\gamma$ and $\phi$ given by

$$
\gamma>1+\frac{1}{\phi}
$$

Restriction (23) is stronger than condition (9), which satisfies inequality (8). For this reason, inequality (22) is a sufficient condition for inequality (8).

\section{The data}

Our empirical analysis is focused on the MED countries. In particular, we consider the following 13 countries: Albania, Algeria, Croatia, Cyprus, Egypt, Greece, Israel, Lebanon, Malta, Morocco, Slovenia, Tunisia and Turkey, organized in three distinct groups according to their geographical position along the MED Sea (Gürlük, 2009): Euro-MED (Albania, Croatia, Greece, Malta and Slovenia), Euro-Asian-MED (Cyprus, Israel, Lebanon and Turkey) and African-MED (Algeria, Egypt, Morocco and Tunisia).

The main variables considered in our analysis are annual aggregate per capita $\mathrm{CO}_{2}$ emissions (metrics tons) and annual aggregate per capita consumption (i.e., aggregate household final consumption expenditure, measured in constant US\$2,000). Data are collected from the World Bank Development Indicators, 2013 Edition. 
We use the growth rate of $\mathrm{CO}_{2}$ emissions as a proxy of environmental pollution, following a common practice within the environmental economic literature (in this respect, see, among others, Friedl and Getzner, 2003; Fodha and Zaghdoud, 2010; Wang, 2012). Actually, $\mathrm{CO}_{2}$ emissions are produced by human activities, such as burning oil, coal and gas for energy use, wood and waste materials, and some industrial processes (e.g., cement production). $\mathrm{CO}_{2}$ is also the reference gas for measuring and evaluating other greenhouse gases. Moreover, it also accounts for the largest share of greenhouse gases contributing to global warming and climate change, as confirmed by the emphasis which many industrial and developing countries, from the Kyoto Protocol onwards, have put on curbing $\mathrm{CO}_{2}$ emissions globally. Finally, $\mathrm{CO}_{2}$ data, differently from other pollutants, are generally available since 1960 .

We define the logarithmic transformations of per capita consumption and $\mathrm{CO}_{2}$ emissions as cons $s_{t}$ and poll, respectively, while $\mathrm{CONS}_{t}$ and

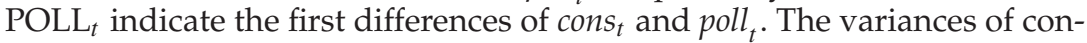
sumption and pollution rates of growth are represented by the variables $V_{A R C O N S}$ and VARPOLL $L_{t}$, respectively, while the covariance between consumption and pollution rates of growth is indicated with $C O V_{t}$. Following Dynan (1993) and Guariglia and Kim (2003), the two variances and the covariance are computed, at each year $t$, using observations of the previous five years.

Table 1 shows the periods of data availability (in general, from 1960 to 2008) for each country. Table 1 also presents the World Bank classification of each country based on per capita gross national income (GNI). According to this classification, Egypt and Morocco are the only lower middle income (LMI) countries in our sample, while Albania, Algeria, Lebanon, Tunisia and Turkey are upper middle income (UMI) countries. Finally, Croatia, Cyprus, Greece, Israel, Malta and Slovenia are classified as high income (HI) countries. ${ }^{6}$ It is worth noticing that the comparison between the three groups highlights that the African-MED countries generally exhibit lower income levels than countries belonging to the two other groups.

Descriptive statistics on the variables of interest are summarized in table 1. Albania is the only country with an average negative consumption rate of growth ( -0.44 per cent). Algeria and Lebanon show the lowest consumption growth rates ( 0.32 per cent and 0.26 per cent, respectively). On the other hand, $\mathrm{CONS}_{t}$ is on average particularly high in HI countries, especially Cyprus (2.18 per cent), Malta (1.85 per cent) and Slovenia (1.80 per cent). With regard to POLL $L_{t}$, Israel is the only country with a sizable, negative pollution growth rate $(-2.14$ per cent) in the period spanned by our data. The growth rate of pollution is also particularly low in Lebanon (0.25 per cent) and Albania ( 0.60 per cent). The highest increments in pollution are recorded in Greece and in all the African-MED countries.

${ }^{6}$ According to the World Bank classification, LMI countries have a per capita GNI between US $\$ 1,036$ and US $\$ 4,085$, UMI countries have a per capita GNI between US $\$ 4,086$ and US $\$ 12,615$, and HI countries have a per capita GNI equal to or greater than US\$12,616. 
Table 1. Descriptive statistics

\begin{tabular}{|c|c|c|c|c|c|c|}
\hline & & Mean & $\operatorname{Max}$ & Min & S.D. & Jarque-Bera \\
\hline \multicolumn{7}{|l|}{ Euro-MED countries } \\
\hline Albania (UMI) & $\mathrm{CONS}_{t}$ & -0.44 & 4.64 & -10.09 & 2.92 & $4.50(0.10)$ \\
\hline 1990-2008 & $\mathrm{POLL}_{t}$ & -0.60 & 23.32 & -27.57 & 9.68 & $6.36(0.04)$ \\
\hline Croatia (HI nonOECD) & $\mathrm{CONS}_{t}$ & 1.64 & 4.12 & -2.01 & 1.53 & $1.52(0.47)$ \\
\hline 1995-2008 & $\mathrm{POLL}_{t}$ & 1.11 & 3.84 & -1.92 & 1.83 & $0.90(0.63)$ \\
\hline Greece (HI OECD) & $\mathrm{CONS}_{t}$ & 1.51 & 4.27 & -0.86 & 1.26 & $0.75(0.68)$ \\
\hline 1970-2008 & $\mathrm{POLL}_{t}$ & 1.85 & 10.77 & -3.59 & 2.76 & $0.72(0.69)$ \\
\hline Malta (HI nonOECD) & $\mathrm{CONS}_{t}$ & 1.85 & 8.47 & -1.07 & 1.88 & $0.96(0.62)$ \\
\hline 1970-2008 & $\mathrm{POLL}_{t}$ & 1.19 & 13.59 & -18.19 & 6.07 & $12.93(0.00)$ \\
\hline Slovenia (HI OECD) & $\mathrm{CONS}_{t}$ & 1.80 & 5.82 & 0.21 & 1.37 & $1.55(0.45)$ \\
\hline $1992-2008$ & $\mathrm{POLL}_{t}$ & 0.73 & 11.02 & -6.59 & 3.53 & $11.39(0.00)$ \\
\hline \multicolumn{7}{|c|}{ Euro-Asian MED countries } \\
\hline Cyprus (HI nonOECD) & $\mathrm{CONS}_{t}$ & 2.18 & 8.69 & -3.11 & 2.29 & $0.80(0.67)$ \\
\hline 1997-2008 & $\mathrm{POLL}_{t}$ & 1.26 & 8.98 & -3.15 & 2.43 & $0.25(0.88)$ \\
\hline Israel (HI OECD) & $\mathrm{CONS}_{t}$ & 0.81 & 2.57 & -0.85 & 0.94 & $0.07(0.96)$ \\
\hline 1995-2008 & $\mathrm{POLL}_{t}$ & -2.14 & 5.57 & -25.98 & 7.59 & $58.25(0.00)$ \\
\hline Lebanon (UMI) & $\mathrm{CONS}_{t}$ & 0.26 & 3.87 & -3.33 & 1.81 & $0.02(0.98)$ \\
\hline 1994-2008 & $P O L L_{t}$ & 0.25 & 4.79 & -7.19 & 3.46 & $1.40(0.50)$ \\
\hline Turkey (UMI) & $\mathrm{CONS}_{t}$ & 1.06 & 4.60 & -3.59 & 2.19 & $1.68(0.43)$ \\
\hline 1987-2008 & $\mathrm{POLL}_{t}$ & 0.95 & 3.63 & -5.20 & 2.36 & $3.64(0.17)$ \\
\hline \multicolumn{7}{|l|}{ African-MED countries } \\
\hline Algeria (UMI) & $\mathrm{CONS}_{t}$ & 0.32 & 24.01 & -12.77 & 5.39 & $17.92(0.00)$ \\
\hline 1960-2008 & $\mathrm{POLL}_{t}$ & 1.57 & 16.83 & -17.04 & 7.22 & $0.35(0.84)$ \\
\hline Egypt (LMI) & $\mathrm{CONS}_{t}$ & 1.18 & 5.31 & -1.10 & 1.36 & $0.70(0.70)$ \\
\hline 1973-2008 & $\mathrm{POLL}_{t}$ & 1.78 & 8.85 & -5.96 & 3.02 & $0.66(0.72)$ \\
\hline Morocco (LMI) & $\mathrm{CONS}_{t}$ & 0.75 & 4.33 & -3.65 & 2.00 & $0.80(0.67)$ \\
\hline 1960-2008 & $P O L L_{t}$ & 1.43 & 9.74 & -10.03 & 3.34 & $0.82(0.66)$ \\
\hline Tunisia (UMI) & $\mathrm{CONS}_{t}$ & 1.33 & 5.48 & -3.48 & 1.84 & $0.43(0.80)$ \\
\hline 1962-2008 & $\mathrm{POLL}_{t}$ & 1.63 & 14.20 & -5.83 & 3.21 & $0.25(0.88)$ \\
\hline
\end{tabular}

Notes: $\mathrm{CONS}_{t}$ and POLL $L_{t}$ are the first differences of the logarithmic transformation of per capita consumption and $\mathrm{CO}_{2}$ emissions, respectively; Jarque-Bera tests the null hypothesis of normal distribution ( $p$-values in parentheses). According to the World Bank classification of the world's economies based on estimates of per capita gross national income (GNI), lower middle income (LMI) countries have a per capita GNI between US $\$ 1,036$ and US $\$ 4,085$, upper middle income (UMI) countries have a per capita GNI US $\$ 4,086$ to US $\$ 12,615$, high income (HI) countries have a per capita GNI equal to or greater than US\$12,616.

The order of integration of the variables involved in model (12) is assessed using the unit root tests of Kwiatkowski et al. (1992) (henceforth KPSS) and Clemente et al. (1998) (henceforth CMR). 
Table 2. Unit root tests

\begin{tabular}{|c|c|c|c|c|}
\hline & $\operatorname{cons}_{t}$ & poll $_{t}$ & $\mathrm{CONS}_{t}$ & $\mathrm{POLL}_{t}$ \\
\hline \multicolumn{5}{|c|}{ Euro-MED countries } \\
\hline \multirow[t]{2}{*}{ Albania } & $0.25^{* *}$ & $0.70^{* *}$ & 0.39 & 0.11 \\
\hline & -1.87 & -2.66 & $-6.72^{* *}$ & $-6.24^{* *}$ \\
\hline \multirow[t]{2}{*}{ Croatia } & $0.57^{* *}$ & $0.51^{* *}$ & 0.22 & 0.14 \\
\hline & -2.57 & -2.12 & $-3.57^{* *}$ & $-4.60^{* *}$ \\
\hline \multirow[t]{2}{*}{ Greece } & $0.89^{* * *}$ & $0.84^{* *}$ & 0.33 & 0.40 \\
\hline & -2.16 & -2.62 & $-5.73^{* *}$ & $-7.05^{* *}$ \\
\hline \multirow[t]{2}{*}{ Malta } & $0.75^{* * *}$ & $0.86^{* * *}$ & 0.38 & 0.34 \\
\hline & -2.46 & -2.91 & $-4.90^{* *}$ & $-6.54^{* *}$ \\
\hline \multirow[t]{2}{*}{ Slovenia } & $0.57^{* *}$ & $0.47^{* *}$ & 0.12 & 0.07 \\
\hline & -1.55 & -2.90 & $-8.64^{* *}$ & $-6.43^{* *}$ \\
\hline \multicolumn{5}{|c|}{ Euro-Asian MED countries } \\
\hline \multirow[t]{2}{*}{ Cyprus } & $0.70^{* *}$ & $0.88^{* *}$ & 0.39 & 0.37 \\
\hline & -2.67 & -2.38 & $-6.77^{* *}$ & $-9.01^{* *}$ \\
\hline \multirow[t]{2}{*}{ Israel } & $0.56^{* *}$ & $0.74^{* *}$ & 0.09 & 0.39 \\
\hline & -2.04 & -2.49 & $-3.79 * *$ & $-3.95^{* *}$ \\
\hline \multirow[t]{2}{*}{ Lebanon } & 0.24 & $0.87^{* *}$ & 0.28 & 0.38 \\
\hline & -1.16 & -2.74 & -4.82 & -4.31 \\
\hline \multirow[t]{2}{*}{ Turkey } & $0.63^{* *}$ & $0.87^{* *}$ & 0.39 & 0.08 \\
\hline & -1.91 & -2.65 & $-4.63^{* *}$ & $-8.67^{* *}$ \\
\hline \multicolumn{5}{|c|}{ African MED countries } \\
\hline \multirow[t]{2}{*}{ Algeria } & $0.49^{* *}$ & $0.69^{* *}$ & 0.12 & 0.28 \\
\hline & -3.34 & -1.26 & $-5.92^{* *}$ & $-4.19^{* *}$ \\
\hline \multirow[t]{2}{*}{ Egypt } & $0.69^{* *}$ & $0.89^{* *}$ & 0.17 & 0.07 \\
\hline & -2.12 & -2.02 & $-5.35^{* *}$ & $-6.34^{* *}$ \\
\hline \multirow[t]{2}{*}{ Morocco } & $0.90^{* *}$ & $0.88^{* *}$ & 0.07 & 0.16 \\
\hline & -1.74 & -1.96 & $-9.84^{* *}$ & $-11.97^{* *}$ \\
\hline \multirow[t]{2}{*}{ Tunisia } & $0.85^{* * *}$ & $0.86^{* * *}$ & 0.11 & 0.39 \\
\hline & -1.57 & -2.68 & $-3.71^{* *}$ & $-5.15^{* *}$ \\
\hline
\end{tabular}

Notes: For each country, two unit root tests are presented, namely KPSS and CRM; KPSS is reported in the first row and assumes that the series is stationary under the null hypothesis; CRM is reported in the second row and assumes that the series has a unit root under the null hypothesis; both tests are calculated by including the intercept in the test equations. CRM is computed with the inclusion of single mean shift (additive outlier model). For KPSS, asymptotic critical values at 1 and $5 \%$ significance levels are 0.74 and 0.46 , respectively; for CRM, the critical value at $5 \%$ significant level is -3.56 and is reported in Perron and

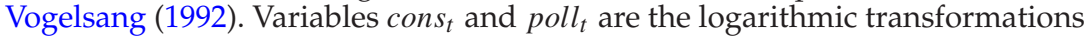
of per capita consumption and $\mathrm{CO}_{2}$ emissions, while $\mathrm{CONS}_{t}$ and $P O L L_{t}$ are their first differences. ${ }^{* *}\left({ }^{* *}\right)$ indicate rejection of the null hypothesis at $5 \%(1 \%)$ significant level, respectively.

As shown in table 2, we find the presence of a unit root for logtransformed per capita consumption and pollution in all countries, while their rates of growth are stationary. ${ }^{7}$

7 The same conclusions hold when one possible structural break is considered. Moreover, the KPSS unit-root test indicates that $\operatorname{cons}_{t}$ in Lebanon is stationary 


\section{Empirical results}

The estimated version of equation (12) is:

$$
\mathrm{CONS}_{t}=\alpha_{0}+\alpha_{1} \text { POLL }_{t}+\alpha_{2} \text { VARCONS }_{t}+\alpha_{3} \text { VARPOLL }_{t}+\alpha_{4} \text { COV }_{t}+u_{t} .
$$

Non-linear restrictions (20) and (21) are imposed on the parameters $\alpha_{1}$, $\alpha_{2}, \alpha_{3}$ and $\alpha_{4}$. In order to take into account problems related to endogeneity, possible biases due to omitted variables and measurement errors which potentially affect $\mathrm{CO}_{2}$ emissions and consumption data (as noted by Carroll, 1997), equation (12) is estimated with the generalized method of moments (GMM). In this last respect, moment conditions are satisfied by instrumenting potentially endogenous variables with their past values. Furthermore, based on the high correlation between the explanatory variables in equation (24) and per capita GDP in each country, lagged values of per capita GDP are also used as instruments. Similarly to CONS $t$ and $P O L L_{t}$, we define the first differences of the logarithmic transformation of per capita GDP as $G D P_{t}$. Furthermore, COVGDP $P_{t}$ and $V A R G D P_{t}$ indicate the covariance between GDP $t_{t}$ and $P O L L_{t}$ and the variance of GDP ${ }_{t}$, respectively. The variance of $G D P_{t}$ is computed following the same procedure used for calculating VARCONS $s_{t}$ and VARPOLL $L_{t}$.

More precisely, since $V A R C O N S_{t}$ is a potentially endogenous variable (see Carroll, 1992; Hahm and Steigerwald, 1999; Menegatti, 2007, 2010; Baiardi et al., 2013), lagged values of GDP ${ }_{t}, V A R C O N S_{t}$ and VARGDP are used as instruments. The potential endogeneity of VARPOLL $L_{t}, P O L L_{t}$ and $\mathrm{COV}_{t}$ is treated by instrumenting the first two variables with their lagged values, while $C O V_{t}$ is instrumented with its own lagged values and the lagged values of $C O V G D P_{t}$. Estimates are obtained by using Heteroskedasticity and Autocorrelation Consistent (HAC) standard errors.

Tables 3, 4 and 5 show the results for each group of countries. The $J$-statistic indicates that the null hypothesis of valid over-identifying restrictions is not rejected in all countries, while residual autocorrelation and heteroskedasticity do not in general affect the estimated equations. ${ }^{8}$ The null hypothesis of residual normal distribution is not rejected by the Jarque-Bera test in most of the countries, with Malta and Cyprus as the only exceptions among the Euro-MED and Euro-Asian MED countries, and Egypt and Morocco among the African-MED countries. Contemporaneous correlations among the residuals obtained from country-by-country

in level. Finally, since VARCONS ${ }_{t}, V A R P O L L_{t}$ and $C O V_{t}$ are directly computed starting from the stationary variables $C O N S_{t}$ and $P O L L_{t}$, we conclude that they are stationary too.

8 There are specific cases of serial correlation and heteroskedasticity in the residuals in Algeria, Cyprus, Greece and Malta. Albania and Egypt show some serial correlation problems in the error term, while heteroskedasticity affects estimation results for Egypt, Morocco and Tunisia. Carroll (1992) states that the presence of serial correlation supports the buffer stock saving hypothesis. 
Table 3. Euro-MED countries: GMM estimation of the regression model (24)

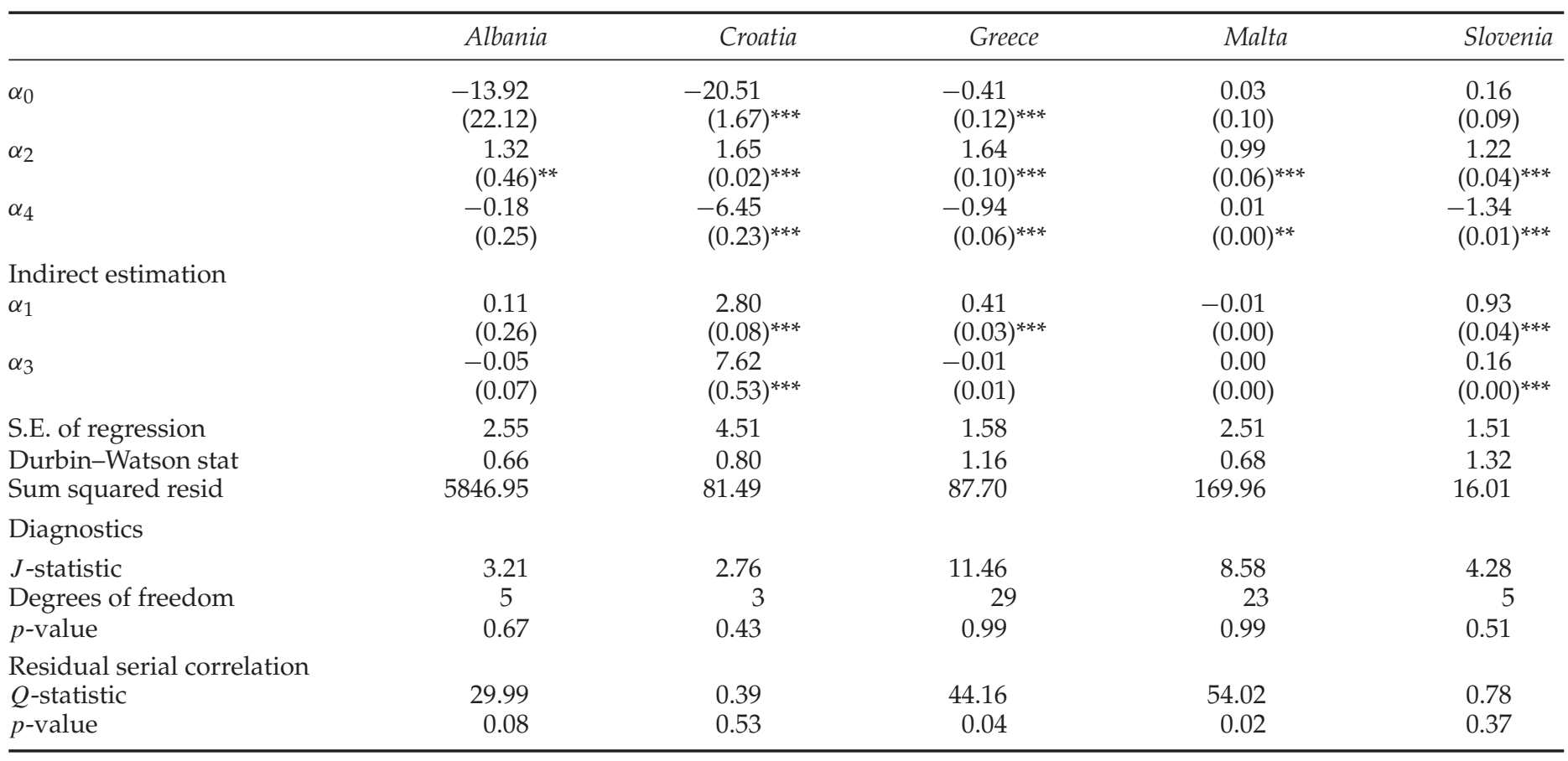

(continued) 
Table 3. Continued

\begin{tabular}{|c|c|c|c|c|c|}
\hline & Albania & Croatia & Greece & Malta & Slovenia \\
\hline \multicolumn{6}{|c|}{ White test for heteroskedasticity } \\
\hline $\mathrm{Obs}^{*} R$-squared & 11.27 & 9.00 & 27.46 & 29.33 & 9.98 \\
\hline$p$-value & 0.19 & 0.34 & 0.00 & 0.00 & 0.26 \\
\hline \multicolumn{6}{|l|}{ Normality test } \\
\hline Jarque-Bera & 0.70 & 0.68 & 0.00 & 23.98 & 0.06 \\
\hline$p$-value & 0.70 & 0.67 & 0.99 & 0.00 & 0.96 \\
\hline
\end{tabular}

Notes: All variables are expressed in log-differences; asymptotic standard errors are reported in brackets. ${ }^{*}(* *)\left[{ }^{* * *}\right]$ indicate significance at 10(5)[1] \% level. A Wald test supports the conclusion that the coefficient $\alpha_{4}$ is smaller than one, as imposed by the theoretical restriction of the model; the $J$-statistic tests the validity of the over-identifying restrictions when the number of instruments is larger than the number of estimated parameters; the $Q$-statistic at lag $k$ tests the null hypothesis of no residual serial correlation up to order $k, k=1, \ldots, 10$; to save space; the $Q$-statistic and the corresponding $p$-value reported in the table are for $k=1$. The White statistic is a test of the null hypothesis of no heteroskedasticity against heteroskedasticity of some unknown general form. The JarqueBera statistic tests the null hypothesis that the standardized residuals are normally distributed. The estimated coefficient covariance matrix is weighted with Kernel Bartlett Bandwidth Fixed without prewhitening for Albania and Croatia; Kernel Quadratic Bandwidth Andrews (with prewhitening) and Kernel Bartlett Bandwidth Andrews (without prewhitening) are used for Greece and Slovenia, respectively. Instruments (I) for each country are: Albania I = [constant, $\left.C O N S_{t-1}, C O V_{t-1}, P O L L_{t-1}, V A R C O N S_{t-1}, V A R P O L L_{t-1}, G D P_{t-1}\right]$;

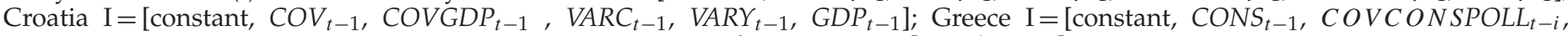

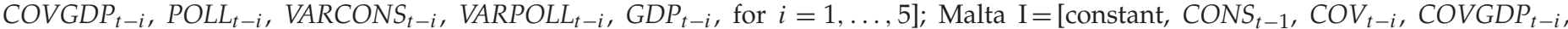

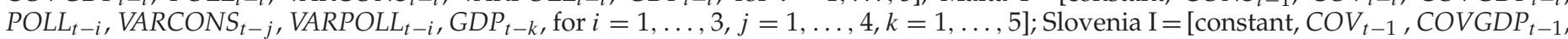

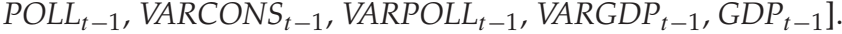


Table 4. Euro-Asian MED countries: GMM estimation of model (24)

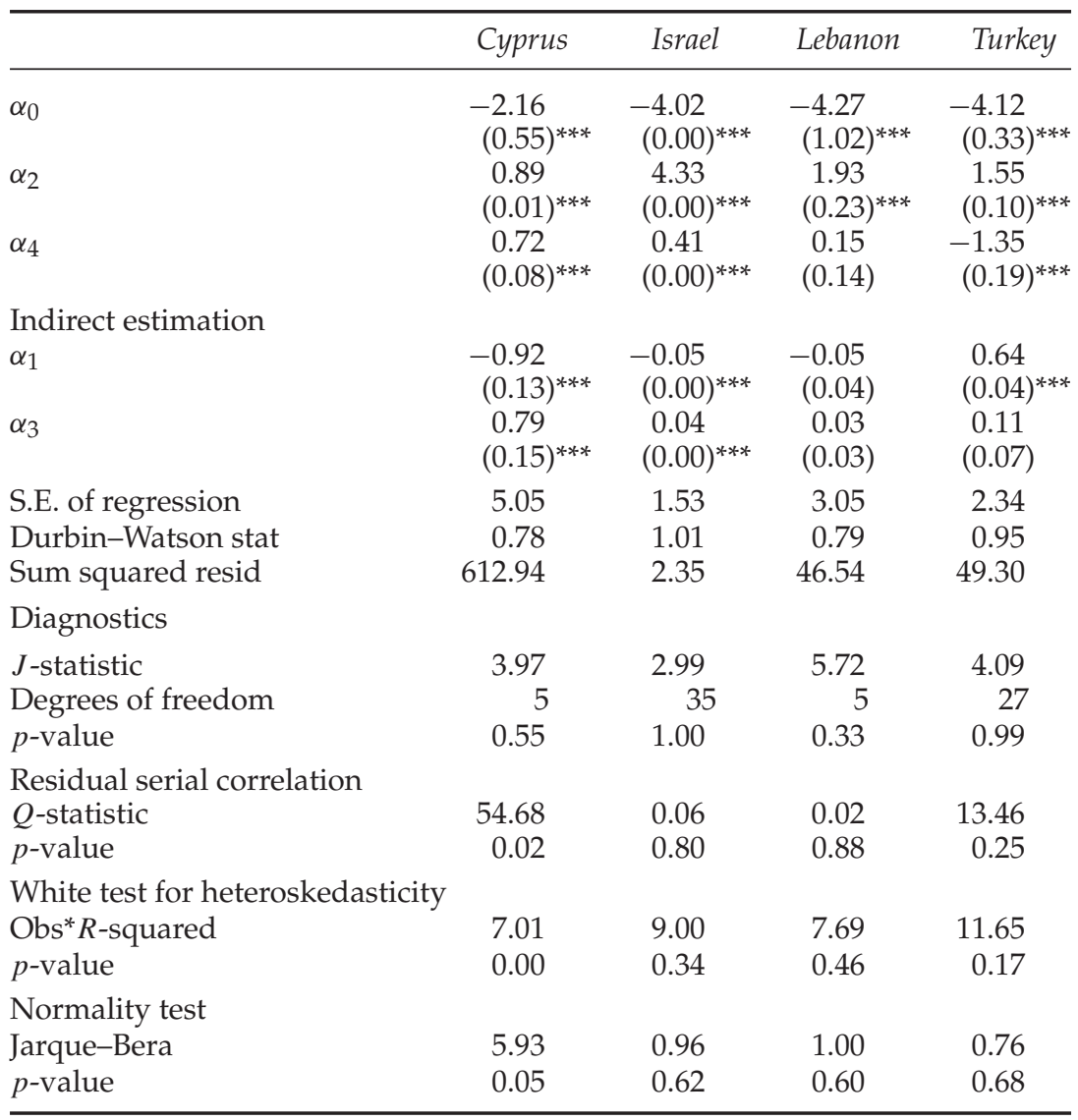

Notes: See table 3. The estimated coefficient covariance matrix is weighted with Kernel Quadratic Bandwidth Andrews (with prewhitening) for Lebanon and Israel and with Kernel Bartlett Bandwidth Andrews (without prewhitening) for Cyprus; Kernel Bartlett Bandwidth Variable Newey-West (1) with prewhitening is used for Turkey. Instruments (I) for each country are: Cyprus I $=\left[\right.$ constant, $C O V_{t-1}, C_{\text {COVGDP }}{ }_{t-1}, \mathrm{P}_{t-1}$, VARCONS $_{t-1}$, VARPOLL $_{t-1}$, $\left.G D P_{t-1}\right]$; Israel $\mathrm{I}=\left[\right.$ constant, $C O V_{t-i}, C O V G D P_{t-i}, P O L L_{t-i}, V_{A R C O N S}$ COR $_{t-i}$, VARPOLL $L_{t-i}, V A R G D P_{t-i}, G D P_{t-j}$, for $i=1, \ldots, 4, j=1, \ldots, 5$ ]; Lebanon $\mathrm{I}=\left[\mathrm{constant}, \mathrm{COV}_{t-1}, \mathrm{COVGDP}_{t-1}, \mathrm{POLL}_{t-1}\right.$, VARCONS $_{t-1}$, VARPOLL $_{t-1}$, $\left.V_{A R G D P}{ }_{t-1}, G D P_{t-1}\right]$; Turkey $\mathrm{I}=\left[\right.$ constant, $C O V_{t-i}, C O V G D P_{t-i}, P O L L_{t-i}$,

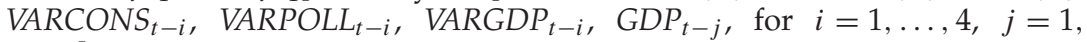
$\ldots, 5]$.

estimation of equation (24) are generally low and statistically insignificant at conventional levels. ${ }^{9}$

${ }^{9}$ Specifically, the $p$-values of the $t$-statistics on the null hypothesis that each correlation coefficient is equal to zero have been computed using the Dunn-Sidak 
Table 5. African-MED countries: GMM estimation of model (24)

\begin{tabular}{|c|c|c|c|c|}
\hline & Algeria & Egypt & Morocco & Tunisia \\
\hline$\alpha_{0}$ & $\begin{array}{c}-0.16 \\
(0.40)\end{array}$ & $\begin{array}{l}0.85 \\
(0.28)^{* * *}\end{array}$ & $\begin{array}{l}2.27 \\
(0.38)^{* * *}\end{array}$ & $\begin{array}{l}1.53 \\
(0.01)^{* * * *}\end{array}$ \\
\hline$\alpha_{2}$ & $\begin{array}{l}0.60 \\
(0.11)^{* * *}\end{array}$ & $\begin{array}{l}2.02 \\
(0.60)^{* * *}\end{array}$ & $\begin{array}{l}-0.48 \\
(0.10)^{* * *}\end{array}$ & $\begin{array}{l}0.57 \\
(0.00)^{* * *}\end{array}$ \\
\hline$\alpha_{4}$ & $\begin{array}{c}0.00 \\
(0.00)\end{array}$ & $\begin{array}{l}-0.08 \\
(0.04)^{*}\end{array}$ & $\begin{array}{l}0.15 \\
(0.04)^{* * * *}\end{array}$ & $\begin{array}{l}-0.03 \\
(0.00)^{* * * *}\end{array}$ \\
\hline \multicolumn{5}{|l|}{ Indirect estimation } \\
\hline$\alpha_{1}$ & $\begin{array}{c}-0.00 \\
(0.00)\end{array}$ & $\begin{array}{c}0.03 \\
(0.02)\end{array}$ & $\begin{array}{l}0.08 \\
(0.02)^{* * *}\end{array}$ & $\begin{array}{l}0.18 \\
(0.00)^{* * *}\end{array}$ \\
\hline$\alpha_{3}$ & $\begin{array}{c}0.00 \\
(0.00)\end{array}$ & $\begin{array}{c}-0.01 \\
(0.00)\end{array}$ & $\begin{array}{c}-0.04 \\
(0.01)\end{array}$ & $\begin{array}{l}-0.09 \\
(0.00)^{* * * *}\end{array}$ \\
\hline S.E. of regression & 5.15 & 1.50 & 2.71 & 1.75 \\
\hline Durbin-Watson stat & 0.32 & 0.27 & 1.67 & 1.28 \\
\hline Sum squared resid & 530.93 & 42.78 & 265.57 & 117.99 \\
\hline \multicolumn{5}{|l|}{ Diagnostics } \\
\hline$J$-statistic & 5.89 & 8.40 & 9.91 & 8.56 \\
\hline Degrees of freedom & 14 & 10 & 10 & 22 \\
\hline$p$-value & 0.97 & 0.59 & 0.45 & 0.99 \\
\hline $\begin{array}{l}\text { Residual serial correl } \\
Q \text {-statistic }\end{array}$ & $\begin{array}{r}12.77 \\
0 \Omega 0\end{array}$ & 91.56 & $\begin{array}{l}0.11 \\
0.74\end{array}$ & $\begin{array}{l}0.09 \\
0.76\end{array}$ \\
\hline \multicolumn{5}{|c|}{ White test for heteroskedasticity } \\
\hline $\mathrm{Obs}^{*} R$-squared & 1.63 & 16.01 & 16.38 & 21.71 \\
\hline$p$-value & 0.04 & 0.04 & 0.03 & 0.00 \\
\hline \multicolumn{5}{|l|}{ Normality test } \\
\hline Jarque-Bera & 2.65 & 15.71 & 21.85 & 2.22 \\
\hline$p$-value & 0.26 & 0.05 & 0.00 & 0.92 \\
\hline
\end{tabular}

Notes: See table 3. The estimated coefficient covariance matrix is weighted with Kernel Bartlett Bandwidth Fixed without prewhitening for Algeria; Kernel Quadratic Bandwidth Andrews (with prewhitening) and Kernel Bartlett Bandwidth Andrews (without prewhitening) are used for Morocco and Egypt, respectively; Kernel Bartlett Bandwidth Variable Newey-West (1) without prewhitening is used for Tunisia. Instruments (I) for each country are: Algeria $\mathrm{I}=\left[\right.$ constant, $\operatorname{CONS}_{t-i}, \mathrm{COV}_{t-i}, \mathrm{VARCONS}_{t-i}, \mathrm{GDP}_{t-i}$, for $\left.i=1, \ldots, 4\right]$; Egypt $\mathrm{I}=\left[\right.$ constant, $V A R C O N S_{t-i}, G D P_{t-i}$ for $\left.i=1, \ldots, 6\right]$; Morocco $\mathrm{I}=[$ constant,

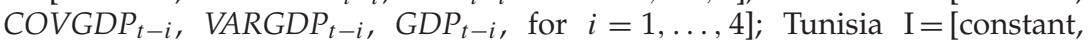
$\mathrm{COV}_{t-i}, \mathrm{COVGDP}_{t-i}, \mathrm{POLL}_{t-i}$, VARCONS $_{t-i}$, VARPOLL $_{t-i}, \operatorname{VARGDP}_{t-i}$, $G D P_{t-i}$, for $\left.i=1, \ldots, 4\right]$.

Coefficient $\alpha_{2}$ analyzes the effects of consumption risk on consumption and saving dynamics. In line with economic theory, we find that $\alpha_{2}$ is

correction for multiple comparison. Moreover, the Morrison (1967) test does not reject the joint null hypothesis that all residual correlation coefficients are zero at conventional significance levels. Results are available on request. 
always positive and highly statistically significant in all three groups of countries, with the only exception being Morocco. This result validates the hypothesis that consumption risk raises precautionary saving in a context where environmental risk is also considered. ${ }^{10}$

Coefficient $\alpha_{3}$ captures the direct effect of environmental risk on consumption growth rate. This parameter is positive, as expected, and statistically significant in half the Euro-MED countries (Croatia and Slovenia) and Euro-Asian-MED countries (Cyprus and Israel). Conversely, $\alpha_{3}$ is not significant in three out of four of the African-MED countries, and actually negative in the case of Tunisia. These results indicate a direct effect of environmental risk on consumption dynamics, although the effect clearly emerges only in a subgroup of Euro-MED and Euro-Asian-MED countries, while it is not as clear in the African-MED countries.

The expected positive sign of coefficient $\alpha_{3}$ is related to aversion toward uncertainty on pollution. ${ }^{11}$ In our sample, the presence of this kind of risk aversion is confirmed only in a sub-group of countries, suggesting that the sensibility to pollution risk is not high in the other MED economies. Coefficient $\alpha_{3}$ is a function of both parameters $\gamma$ and $\phi$. Consequently, this empirical result may depend either on the level of risk aversion or on the level of concern toward environmental quality.

Coefficient $\alpha_{4}$ measures the indirect effect of the interaction between environmental and consumption risks. It is highly significant and less than 1 for almost all countries, as required by the theoretical constraint of our model. ${ }^{12}$ This means that the interaction between consumption and environmental risks is relevant in determining consumption growth. This conclusion, together with previous findings on coefficient $\alpha_{3}$, suggests that the influence of environmental risk on consumption dynamics is indirect, i.e., through its interaction with consumption risk.

Additional constraint (22) finally suggests a positive sign for coefficient $\alpha_{1}$, which measures the effect of environmental degradation on consumption growth. The expected sign is confirmed in our estimates for eight countries out of 13, mostly in the subgroup of Euro-MED countries.

To summarize, we find that the coefficients generally have the expected sign in most of the Euro-MED and the Euro-Asian MED countries. The African-MED countries are instead characterized by less clear-cut evidence:

10 The traditional literature does not consider environmental risk explicitly, whereas the precautionary saving hypothesis is only indirectly identified with the introduction of the saving rate as the dependent variable in the estimated equations, instead of the consumption rate of growth (see, for example, Hahm and Steigerwald, 1999; Menegatti, 2007, 2010). Different reasons, such as alternative assumptions about the utility function, which may not be a CRRA, consumer impatience (Carroll, 1992) and gradual adjustment of saving or changes in the degree of income uncertainty, have been put forward to justify the traditional approach.

11 As already pointed out, this is a stronger requirement than aversion toward uncertainty on environmental quality.

12 Wald test statistics support the conclusion that the estimated values of $\alpha_{4}$ satisfy the theoretical condition $\alpha_{4}<1$ at conventional significance levels. 
the variables which proxy consumption risk and the interaction between environmental and consumption risks (whose coefficients are $\alpha_{2}>0$ and $\alpha_{4}<1$, respectively) exhibit the expected marginal effects on consumption dynamics (with the only exception being Morocco), whereas the evidence of the influence of environmental risk on consumption (measured by parameters $\alpha_{1}$ and $\alpha_{3}$ ) is less robust.

These findings can be interpreted in the light of the strong economic, social and cultural differences which characterize the MED countries. In particular, as highlighted in table 1, the MED countries show significant differences in terms of development. Furthermore, as already noted in the previous section, pollution considerably increased in all the African countries during the time period taken into account. These stylized facts, together with the deep structural changes that have affected these emerging economies, have important consequences in terms of environmental preferences, which are discussed at the end of the following section.

\section{Estimates of risk aversion and prudence}

The results obtained in the previous section can be used to derive estimates for the parameters $\gamma$ and $\phi$ in the utility function (10) which are specific to each MED country. Table 6 reports the estimated parameters $\gamma$ and $\phi$, together with the indices of partial relative risk aversion and partial relative prudence, for the three groups of countries. The two indices directly depend on the magnitude of the parameter $\gamma$, since they equal $-\frac{U_{C C} C_{t}}{U_{C}}=\gamma$ and $-\frac{U_{C C C} C_{t}}{U_{C C}}=1+\gamma$, respectively. According to Gollier (2003), if the utility function is a CRRA, plausible values of the relative risk aversion index (and, consequently, of $\gamma$ ) vary from 1 to 4 .

In general, we find that the presence of two sources of uncertainty provides reasonable estimates for parameters $\gamma$ and $\phi .{ }^{13}$ With regard to parameter $\gamma$, it is worth noticing that our results confirm the conclusions reached by Baiardi et al. (2013), who interpret the omission of relevant sources of uncertainty, such as environmental risk, as the main cause of the implausible estimates of the relative risk aversion index based on consumption risk only (Dynan, 1993).

More specifically, we find that the parameter $\gamma$ varies from 0.94 to 2.31 among the Euro-MED countries. The most risk-averse countries in this group are Croatia (2.31) and Greece (2.28), while the least risk averse is Malta, where the parameter is fairly low (0.98), but not different from 1 at the 5 per cent significance level.

The Euro-Asian MED countries show the highest variability in this parameter, which assumes values ranging from 0.78 to 2.85 . In this group, Lebanon and Turkey are the most risk-averse countries (2.85 and 2.11, respectively), while Cyprus is the least risk-averse country (0.78). The estimated value of $\gamma$ for Israel is too high, at least according to the literature.

13 These conclusions also hold when the issue of parameter stability is tackled using recursive estimation. The results, which generally support the stability of the parameter values shown in table 6 , are available on request. 
Table 6. Estimation of relative risk aversion, relative prudence and relative preference for environmental quality

\begin{tabular}{|c|c|c|c|c|}
\hline & $\gamma$ & $\phi$ & $\begin{array}{l}\text { Relative } \\
\text { risk aversion }\end{array}$ & $\begin{array}{l}\text { Relative } \\
\text { prudence }\end{array}$ \\
\hline \multicolumn{5}{|l|}{ Euro-MED countries } \\
\hline Albania & $\begin{array}{c}1.64 \\
(0.93)\end{array}$ & $\begin{array}{c}0.28 \\
(0.78)\end{array}$ & 1.64 & 2.64 \\
\hline Croatia & $\begin{array}{c}2.31 \\
(0.03)\end{array}$ & $\begin{array}{c}4.94 \\
(0.13)\end{array}$ & 2.31 & 3.31 \\
\hline Greece & $\begin{array}{c}2.28 \\
(0.19)\end{array}$ & $\begin{array}{c}0.73 \\
(0.09)\end{array}$ & 2.28 & 3.28 \\
\hline Malta & $\begin{array}{c}0.98 \\
(0.12)\end{array}$ & $\begin{array}{c}0.38 \\
(2.34)\end{array}$ & 0.98 & 1.98 \\
\hline Slovenia & $\begin{array}{c}1.44 \\
(0.08)\end{array}$ & $\begin{array}{c}3.05 \\
(0.52)\end{array}$ & 1.44 & 2.44 \\
\hline \multicolumn{5}{|l|}{ Euro-Asian MED countries } \\
\hline Cyprus & $\begin{array}{c}0.78 \\
(0.03)\end{array}$ & $\begin{array}{c}3.30 \\
(0.07)\end{array}$ & 0.78 & 1.78 \\
\hline Israel & $\begin{array}{c}7.66 \\
(0.00)\end{array}$ & $\begin{array}{c}-0.06 \\
(0.00)\end{array}$ & 7.66 & 8.66 \\
\hline Lebanon & $\begin{array}{c}2.85 \\
(0.45)\end{array}$ & $\begin{array}{c}-0.08 \\
(0.06)\end{array}$ & 2.85 & 3.85 \\
\hline Turkey & $\begin{array}{c}2.11 \\
(0.28)\end{array}$ & $\begin{array}{l}1.23 \\
(0.08)\end{array}$ & 2.11 & 3.11 \\
\hline \multicolumn{5}{|l|}{ African-MED countries } \\
\hline Algeria & $\begin{array}{c}0.21 \\
(0.22)\end{array}$ & $\begin{array}{c}0.00 \\
(0.00)\end{array}$ & 0.21 & 1.21 \\
\hline Egypt & $\begin{array}{c}3.03 \\
(1.21)\end{array}$ & $\begin{array}{c}0.04 \\
(0.04)\end{array}$ & 3.03 & 4.03 \\
\hline Morocco & $\begin{array}{c}-1.96 \\
(0.20)\end{array}$ & $\begin{array}{c}0.05 \\
(0.01)\end{array}$ & -1.96 & -0.96 \\
\hline Tunisia & $\begin{array}{c}0.14 \\
(0.01)\end{array}$ & $\begin{array}{c}-0.03 \\
(0.00)\end{array}$ & 0.14 & 1.14 \\
\hline
\end{tabular}

Notes: Asymptotic standard errors are reported in brackets. The relative risk aversion index is equal to $-\frac{U_{C C} C_{t}}{U_{C}}=\gamma$. The relative prudence index is equal to $-\frac{U_{C C C} C_{t}}{U_{C C}}=1+\gamma$. Indirect estimates from tables 3,4 and 5 .

Focusing on the African-MED countries, we note that Egypt is the only country with a plausible value of the parameter $\gamma$, which is equal to 3.03. For Algeria and Tunisia, $\gamma$ is positive as expected, but it shows values which are too low and inconsistent with the theoretical indications provided by Gollier (2003). In case of Morocco, this parameter is actually negative. These results may be due to the specific characteristics of these countries. In particular, the literature shows the significant role played in these countries by additional sources of uncertainty, such as political risk (see, among others, Al Khattab et al., 2008; Komendantova et al., 2012). 
Furthermore, our results may be influenced by the relative size of personal remittances, which are a significant source of funds in North Africa (World Bank Development Indicators, 2013). ${ }^{14}$ When personal remittances are high, the consumption growth rate may be affected by the variability of income in foreign countries, in addition to the variability of domestic income.

Considering all the MED countries together, our estimates imply that Egypt is the most risk-averse country (3.03), followed by Lebanon (2.85), Croatia (2.31) and Greece (2.28). The least risk-averse countries are Cyprus and Malta (0.78 and 0.98, respectively). Excluding the implausible estimates obtained for Israel among the Euro-Asian MED group and for the African-MED countries (as already noted, Egypt is the only exception), we find that the Euro-MED countries are less risk averse (relative risk aversion is on average equal to 1.60) than Euro-Asian MED countries ( $\gamma$, on average, is equal to 1.91). Moreover, given that the relative prudence index is equal to $\gamma+1$, the estimates for this index range between 1.78 and 4.03 . These results suggest the presence of a strong precautionary saving motivation in Egypt, Lebanon, Greece, Croatia and Turkey, which becomes less intense for Albania and Slovenia, and reaches its lowest levels in Cyprus and Malta.

Table 6 also proposes the estimates of parameter $\phi$, which, according to Ayong Le Kama and Schubert (2004), measures the relative preference of agents for environmental quality. As expected, this parameter shows positive values. Israel, Lebanon and Tunisia are the only exceptions, since this parameter is negative, although very close to zero. If we exclude countries with a negative value of $\phi$, the Euro-MED and the Euro-Asian MED groups prove to be environmentally concerned (with preference levels toward the environment, on average, equal to 2.21 and 2.26 , respectively). The opposite holds for African-MED countries, where $\phi$ is near to zero.

Our findings on the cross-country variability of the values of parameter $\phi$ can also be interpreted according to a complementary point of view. Starting from the World Bank classification of the world's economies reported in table 1 , the countries included in our analysis can be divided into two groups: higher income economies (Croatia, Cyprus, Greece, Israel, Malta and Slovenia) and lower income economies (Albania, Algeria, Egypt, Lebanon, Morocco, Turkey and Tunisia). ${ }^{15}$ Parameter $\phi$ generally exhibits

14 According to the World Bank classification, personal remittances are computed by considering personal transfers and compensation of employees. The first element consists of all current transfers (in cash or in other nature) between resident and non-resident individuals, while the second element refers to the income of border, seasonal and other short-term workers, who are employed in an economy where they are not resident and of residents employed by non-resident entities. Remittances account for 6.97 per cent of total GDP in Morocco (the only country in our sample where the parameter $\gamma$ is negative), 5.96 per cent in Egypt and 4.04 per cent in Tunisia.

${ }^{15}$ In particular, the group of higher income economies identifies $\mathrm{HI}$ countries, both OECD and non-OECD, while the group of lower income economies includes UMI and LMI countries. 
higher values in the first group than in the second, where this indicator tends to be close to zero. This finding is in line with Arouri et al. (2012), who provide evidence in favor of the environmental Kuznets curve hypothesis (EKC) in the MED region, when $\mathrm{CO}_{2}$ emissions are considered as a proxy of environmental degradation. ${ }^{16}$ This implies that only when higher levels of income are achieved do people recognize the importance of a clean environment and move toward more sustainable consumption. As noted above, our results support the EKC, since higher levels of preference toward the environment are recorded in the higher income nations of the sample, while lower income countries generally do not present awareness about environmental issues.

The reasoning above provides a possible justification for the specific results which characterize the African MED countries. The very low values of parameter $\phi$ in these economies are also coherent with the most recent findings within the empirical environmental and energy literature, which provide empirical evidence supporting poor environmental concern in North African nations (M'henni, 2005; Gürlük, 2009; Fodha and Zaghdoud, 2010; Arouri et al., 2012).

Our conclusions on parameters $\gamma$ and $\phi$ are strictly related to the low effect of pollution growth rate and environmental risk on consumption dynamics captured by coefficient $\alpha_{3}$. As shown by inequality (22), a low level of concern toward the quality of environment and a low value of risk aversion potentially contradict the assumption of pollution risk aversion, which determines the expected sign of $\alpha_{3}$. As a consequence, the elements that justify low values of $\gamma$ and $\phi$ can also provide some rationale for the low values of coefficient $\alpha_{3}$.

Lastly, as shown in section 3, our model also implies constraints (9) and (23) on parameters $\gamma$ and $\phi$. Restriction (9) holds in 10 out of 13 countries, with Israel, Lebanon and Tunisia as the only exceptions. On the other hand, restriction (23) is satisfied by Croatia, Slovenia, Israel, Lebanon, Turkey and Tunisia. These results may be due to the specific functional form postulated to describe the relationship between environmental quality and pollution (i.e., $E_{t}=P_{t}^{-1}$ ), which implies that inequality (23) is a stronger condition than (9). Moreover, environmental quality is a very complex phenomenon, characterized by other dimensions that are not completely captured by the pollution variable.

\section{Conclusions}

This paper investigates the effects of environmental and consumption risks on consumption dynamics in the MED area. In particular, we analyzed 13 countries (Albania, Algeria, Croatia, Cyprus, Egypt, Greece, Israel,

16 The EKC postulates an inverse U-shaped relationship between per capita pollution and per capita income. The basic idea is that, as income increases, emissions increase as well, until some threshold level of income is reached after which the trend reverses. 
Lebanon, Malta, Morocco, Slovenia, Tunisia and Turkey) over the period 1965-2008.

Our results show a positive and statistically significant influence of consumption risk on the growth rate of consumption in all countries, with Morocco as the only exception. Our estimates confirm the key role of the interaction between environmental and consumption risks on consumption. We also find evidence of a direct influence of environmental risk on consumption growth rate, although the results are less clear cut when considering the less developed MED economies.

We have also estimated some indices of agents' attitude toward risk, such as the relative risk aversion and the relative prudence indices, and an index measuring the relative preference toward the quality of environment. Our findings suggest that the Euro-Asian MED countries are the most risk averse, while the Euro-MED countries are less risk averse. Moreover, both groups of countries show a pronounced awareness for the level of environmental quality.

On the other hand, very low values are obtained in the African-MED subregion (which includes the lowest income countries) for both the relative risk aversion and the relative prudence indices, as well as for the relative preference toward environmental quality. We argue that a possible explanation for these findings may be related to the presence of additional important sources of uncertainty in the North African MED area, and to the role of remittances. The introduction of these effects into our theoretical model is on our future research agenda.

Finally, our results on the preferences of each country for the quality of environment are coherent with the conclusions of the EKC literature, since less developed countries are less concerned about the environment. The linkage between our approach and the EKC literature could be the basis for another, potentially promising line of research.

\section{References}

Al Khattab, A., J. Anchor, and S. Davies (2008), 'The Institutionalization of Political Risk Assessment (IPRA) in Jordanian international firms', International Business Review 17(6): 688-702.

Arouri, M.E.H., A.N. Youssef, H. M'henni, and C. Rault (2012), 'Energy consumption, economic growth and $\mathrm{CO}_{2}$ emissions in Middle East and North African countries', Energy Policy 45: 342-349.

Ayong Le Kama, A. and K. Schubert (2004), 'Growth, environment and uncertain future preferences', Environmental and Resources Economics 28(1): 31-53.

Baiardi, D. and M. Menegatti (2011), 'Pigouvian tax, abatement policies and uncertainty on the environment', Journal of Economics 103(3): 221-251.

Baiardi, D., M. Manera, and M. Menegatti (2013), 'Consumption and precautionary saving: an empirical analysis under both financial and environmental risks', Economic Modelling 30: 157-166.

Baiardi, D., M. De Donno, M. Magnani, and M. Menegatti (2015), 'New results on precautionary saving under two risks', Economics Letters 130: 17-20.

Bande, R. and D. Riveiro (2013), 'Private saving rates and macroeconomic uncertainty: evidence from Spanish regional data', Economic and Social Review 44(3): 323-349. 
Cambini, C. and D. Franzi (2013), 'Independent regulatory agencies and rules harmonization for the electricity sector and renewables in the Mediterranean region', Energy Policy 60: 179-191.

Carroll, C. (1992), 'The buffer-stock theory of saving: some macroeconomic evidence', Brookings Papers on Economic Activity 2: 61-156.

Carroll, C. (1997), 'Buffer-stock saving and the life cycle/permanent income hypothesis', Quarterly Journal of Economics 112(1): 1-55.

Clemente, J., A. Montañés, and M. Reyes (1998), 'Testing for a unit root in variables with a double change in the mean', Economic Letters 59(2): 813-836.

Courbage, C. (2014), 'Saving motives and multivariate precautionary premia', Decisions in Economics and Finance 37(2): 385-391.

Courbage, C. and B. Rey (2007), 'Precautionary saving in the presence of other risks', Economic Theory 32(2): 417-424.

Denuit, M.M., L. Eeckhoudt, and M. Menegatti (2011), 'Correlated risks, bivariate utility and optimal choices', Economic Theory 46(1): 39-54.

Dynan, K.E. (1993), 'How prudent are consumers?', Journal of Political Economy 101(6): 1104-1113.

Eeckhoudt, L., B. Rey, and H. Schlesinger (2007), 'A good sign for multivariate risk taking', Management Science 53(1): 117-124.

ENP (2004), 'European Neighbourhood Policy overview', Brussels: European Neighbourhood Policy, [available at] http:/ / eeas.europa.eu/enp/.

EU (2006), 'Development of the Mediterranean De-pollution Initiative: Horizon 2020', European Commission Report, December, Athens, [Available at] http:/ / ec.europa.eu/programmes/horizon2020/.

Fan, L., B.F. Hobbs, and C. Norman (2010), 'Risk aversion and $\mathrm{CO}_{2}$ regulatory uncertainty in power generation investment: policy and modeling implications', Journal of Environmental Economics and Management 60(3): 193-208.

Fan, L., C. Norman, and A.G. Patt (2012), 'Electricity capacity investment under risk aversion: a case study of coal, gas, and concentrated solar power', Energy Policy 34(1): 54-61.

Fodha, M. and O. Zaghdoud (2010), 'Economic growth and pollutant emissions in Tunisia: an empirical analysis of the environmental Kuznets curve', Energy Policy 30(2): 1150-1156.

Friedl, B. and M. Getzner (2003), 'Determinants of $\mathrm{CO}_{2}$ emissions in a small open economy', Ecological Economics 45 (1): 133-148.

Giles, J. and K. Yoo (2007), 'Precautionary behavior, migrant networks, and household consumption decisions: an empirical analysis using household panel data from rural China', Review of Economics and Statistics 89(3): 534-551.

Gollier, C. (2003), The Economics of Risk and Time, Cambridge, MA: MIT Press.

Guariglia, A. and B.-Y. Kim (2003), 'The effects of consumption variability on saving: evidence from a panel of Muscovite households', Oxford Bulletin of Economics and Statistics 65(3): 357-377.

Gürlük, S. (2009), 'Economic growth, industrial pollution and human development in the Mediterranean region', Ecological Economics 68(8): 2327-2335.

Hahm, J.H. (1999), 'Consumption growth, income growth and earnings uncertainty: simple cross-country evidence', International Economic Journal 13(2): 39-58.

Hahm, J.H. and D.G. Steigerwald (1999), 'Consumption adjustment under time-varying income uncertainty', Review of Economics and Statistics 81(1): 32-40.

Hall, R.E. (1978), 'Stochastic implication of the life cycle-permanent income hypothesis: theory and evidence', Journal of Political Economy 86(6): 971-987.

Heal, G.M. (1984), 'Interaction between economy and climate: a framework for policy design uncertainty', in V.K. Smith and A.D. White (eds), Advances in Applied Microeconomics, Volume 2, Greenwich, CT: JAI Press. 
IAM (2012), 'International Augmented Med (I AM)', [Available at] http://www. iam-project.eu/.

Jablonski, S., M. Tarhini, M. Touati, D.G. Garcia, and J. Alario (2012), 'The Mediterranean Solar Plan: project proposals for renewable energy in the Mediterranean Partner Countries region', Energy Policy 44: 291-300.

Jacobson, M.Z. and M.A. Delucchi (2010), 'Providing all global energy with wind, water, and solar power, Part I: technologies, energy resources, quantities and areas of infrastructure, and materials', Energy Policy 39(3): 11-40.

Kagiannas, A.G., D.T. Askounis, K. Anagnostopoulos, and J. Psarras (2003), 'Energy policy assessment of the Euro-Mediterranean Cooperation', Energy Conversion and Management 44(16): 2665-2686.

Karakosta, C. and J. Psarras (2013), 'Understanding CDM potential in the Mediterranean Basin: a country assessment of Egypt and Morocco', Energy Policy 60: 827-839.

Karakosta, C., H. Doukas, and J. Psarras (2010), 'EU-MENA energy technology transfer under the CDM: Israel as a frontrunner?', Energy Policy 38(5): 2455-2462.

Keeler, K., B.M. Bolker, and D.F. Bradford (2004), 'Uncertain climate thresholds and optimal economic growth', Journal of Environmental Economics and Management 48(1): 723-741.

Komendantova, N., A. Patt, L. Barras, and A. Battaglini (2012), 'Perception of risks in renewable energy projects: the case of concentrated solar power in North Africa', Energy Policy 40: 103-109.

Kwiatkowski, D., P.C.B. Phillips, P. Schmidt, and Y. Shin (1992), 'Testing the null of stationarity against the alternative of a unit root: how sure are we the economic time series have a unit root', Journal of Econometrics 54(1): 159-178.

Lyhagen, J. (2001), 'The effect of precautionary saving on consumption in Sweden', Applied Economics 33(5): 673-681.

MedSeA (2011), 'European Mediterranean Sea acidification in a changing climate', [Available at] http://medsea-project.eu/.

Menegatti, M. (2007), 'Consumption and uncertainty: a panel analysis in Italian regions', Applied Economic Letters 14(1): 39-42.

Menegatti, M. (2009a), 'Precautionary saving in the presence of other risks: a comment', Journal of Economics 39(3): 473-476.

Menegatti, M. (2009b), 'Optimal saving in the presence of two risks', Journal of Economics 96(3): 277-288.

Menegatti, M. (2010), 'Uncertainty and consumption: new evidence in OECD countries', Bulletin of Economic Research 62(3): 227-242.

M'henni, H. (2005), 'Economic development, adjustment and environmental quality: the case of Tunisia for a contingent valuation study', New Medit 4(2): 36.

Morrison, D.F. (1967), Multivariate Statistical Methods, New York: McGraw-Hill.

MSSD (2005), 'Mediterranean Strategy for Sustainable Development', [Available at] http:/ / www.unepmap.org/index.php? module=content2\&catid=001017002001.

Perron, P. and T. Vogelsang (1992), 'Nonstationarity and level shifts with an application to purchasing power parity', Journal of Business and Economic Statistics 10(3): 310-320.

Pindyck, R.S. (2000), 'Irreversibilities and the timing of environmental policy', Resource and Energy Economics 22(3): 233-260.

Pindyck, R.S. (2002), 'Optimal timing problems in environmental economics', Journal of Economics Dynamics 26(9): 1677-1697.

Reiche, D. (2010), 'Energy policies of Gulf Cooperation Council (GCC) countries possibilities and limitations of ecological modernization in Rentier states', Energy Policy 38(5): 2395-2403. 
Smulders, S. and R. Gradus (1996), 'Pollution abatement and long-term growth', European Journal of Political Economy 12(3): 505-532.

Soretz, S. (2007), 'Efficient dynamic pollution taxation in an uncertain environment', Environmental and Resource Economics 36(1): 57-84.

Ulph, A. and D. Ulph (1997), 'Global warming, irreversibility and learning', Economic Journal 107(442), 636-650.

UNEP/MAP (2004), Reference Handbook on Environmental Compliance and Enforcement in the Mediterranean Region, UNEP/MAP Technical Report Series No. 150, Athens, [Available at] http://www.unepmap.org/.

Wang, K.M. (2012), 'Modeling the nonlinear relationship between $\mathrm{CO}_{2}$ emissions from oil and economic growth', Economic Modelling 29(5): 1537-1547. 